Published in:

Interrogating the neoliberal lifecycle: The limits of success [ISBN:

9783030007690] / edited by Beverley Clack and Michele Paule

(Palgrave Macmillan, 2019).

\title{
Girl Trouble: Not THE IdEAL Neoliberal SubJect
}

\section{Michele Paule}

In this chapter I take as a starting point the figure of the 'successful girl' as she appears in popular and educational discourses as the ideal neoliberal subject (Harris 2005; McRobbie 2008), one that simultaneously reproduces and elides entrenched structures of privilege and power (Baker 2010) within a particular context that produces her as successful - that of 'gifted and talented' policy in the English education system of the early $21^{\text {st }}$ Century. My interest lies in ways in which individual girls make sense of their lives in school contexts where they are enjoined to be successful within identifiably neoliberal parameters.

The late twentieth and early twenty-first centuries saw a burgeoning interest in researching the conditions neoliberalism creates for girls, and in the lived experiences of girls within such conditions (Mendick 2013). This is evident in proliferation of studies focusing on issues of agency, of possibility, and of limitation that create both the 'successful girl' of neoliberal, postfeminist optimism and her shadow twin, the 'at risk' girl (Gonick 2006, Ringrose 2012). Such studies seek to understand better the relationship between girlsas-subjects and the social structures that shape their experiences; they contribute to the challenging of the (neo)liberal view of the subject as the rational, knowing and self-reflexive constructer of life plans (Harris and Dobson 2015)

The possibilities and limitations that shape girls' lives in the UK underwent a variety of changes from the mid-twentieth century, following the success of 
feminism in removing some key legal and cultural barriers to equality (Gonick 2006; Harris and Dobson 2015) and the changes in global markets and employment patterns that saw more women enter the workforce and form new consumer markets (ONS 2013). These elements combined in creating a shift towards recognising girls and women as potentially self-determining subjects (Johnson 1993). The late 1990s in particular saw the rise of new manifestations of feminised success in the popular proliferation of 'girl power' and 'alpha girl' discourses, offering new forms of feminism which were pleasurable, individualised and blame-free (Hollows and Moseley 2006), based on the assumption that gender equality had already been achieved and need only be invoked in the cause of individual fulfilment (McRobbie 2008). Since the 2008 global financial crisis, neoliberal policies have become more firmly entrenched under the flag of austerity. The exhortations to girls to become more resilient and more successfully self-managing have become more insistent at the same time as the burden of austerity lies more heavily on women's shoulders (Allen 2013; De Henau and Reed 2016; Mendick et al. 2018).

The rise of new girlhood discourses is historically contingent with the increasing neoliberalisation of education policy in the UK. This saw the liberal view of education - with its broad objective of 'the development of the common and distinctively human capacities to be exercised in all aspects of life' (Crittenden 2006) - give way to one in which students are conceived of foremost as human capital and as future contributors to the nation's capacity to participate in global economies (Patrick 2013). The resonances between neoliberalism and postfeminism are complex and multi-layered, but have been usefully summarised by Gill \& Scharff (2011) as underpinned by their shared model of self-responsibility, by their construction of the subject as 
autonomous and freely-choosing and, significantly, by the ways in which both suggest how 'to a much greater extent than men, women are required to work on and transform the self, to regulate every aspect of their conduct, and to present all their actions as freely chosen'. 'Could it be', they ask, with a stylistic nod to global postfeminist heroine par excellence, Carrie Bradshaw1, 'that neoliberalism is always already gendered, and that women are constructed as its ideal subjects?' (p.7)

At the turn of the millennium there are certainly indications of culture being seen as increasingly feminised-these emerge in policy discourse, in the popular imaginary, and in education. For example, in 1997 Demos, a crossparty think tank specialising in social policy, produced a report entitled Tomorrow's Women. Its authors state that 'Women's importance in society is set to rise ... women will soon make up the majority of the workforce and Britain is becoming increasingly shaped by feminised values' (Wilkinson et al. 1997, p.8). The 'feminisation' of school cultures was an increasingly common narrative in the late $1990 \mathrm{~s}$ as girls began to overtake boys in public examination performance. This provoked not only celebration of the apparent confirmation that feminism had accomplished a key goal in countering the patriarchal nature of schools (Bernstein, 1978), but also acute cultural anxieties (Ringrose 2013): In popular accounts, the success of girls was positioned in causal opposition to the failure of boys. It was frequently ascribed to supposedly 'feminised' school curricula in which the diligence, self-management and co-operation fostered by coursework are seen to favour girls and to disadvantage boys, whose more mercurial brilliance is better

\footnotetext{
1 Carrie Bradshaw is the lead character of the HBO drama Sex and The City. A writer, Carrie in each episode poses a rhetorical question framing a contemporary problem for the privileged postfeminist woman.
} 
suited to the vigour and challenge of exams (Francis and Skelton, 2005; Elwood, 2010; Jackson and Nystrom 2014). However, whether celebratory or anxious, the school data that prompted both these kinds of responses tended to provoke simplified assumptions about gender as a category and to conceal entrenched differences in performance between the privileged and the disadvantaged (Ringrose and Epstein 2017). Not all boys were doing badly and by no means were all girls doing well (Featherstone et al. 2010; Ringrose 2012). Even among those girls who are the supposed beneficiaries of feminised school cultures, there are complexities and exclusions hidden within the optimistic simplicity of 'successful girl' narratives2, and tensions with the ideal competitive subject of neoliberalism (Foucault 2008).

\section{'Gifted and talented' policy and governmentality}

There is a particular 'success' discourse surrounding 'gifted and talented' policy, expressed via specific terminologies, identificatory measures and school practices introduced into the UK education system by Tony Blair's New Labour government. The production of 'gifted' identities for pupils in schools provides opportunities for examining not only the claims of a particular neoliberal policy to improve individual life chances, but also how it 'gets inside' the individual so identified through its formalised creation of a 'successful' identity, and through its interventions and monitoring practices3.

The recognition of high ability in students, by teachers and via formal testing, has long been bound up in the sedimented gendered, classed and racialised

\footnotetext{
$2 \mathrm{I}$ explore these narratives as they circulate in schools and in media and online cultures in Girlhood, Schools and Media: Discourses of the achieving girl in schools, on screen and online (Routledge, 2016) 3 This addresses address concerns raised by Hook (2007) and Gill and Scharff (2011) in focusing in on the 'mentality' as well as the 'government' aspects of Foucualt's (2009) neoliberal governmentality.
} 
performances that enable or inhibit certain kinds of recognition - the kinds of performativity described by Judith Butler (1997). However, the 'gifted and talented' pupil, identified and placed on a register through the operations of state policy, is also called into being through an official, formalised process, as in Austin's (1977) perlocutionary act which simultaneously produces the thing it pronounces. In schools, registers of 'gifted and talented' pupils in year group cohorts and subjects were used to track progress, to report back to the government, to manage pupils' transitions between schools or between stages of schooling, and to ration access to certain kinds of learning and extracurricular experiences. The newly-pronounced 'gifted and talented' identities were carried beyond school gates into families and communities as letters were sent to parents to inform them that their child had been endowed with this status. 'Gifted and talented' policies and practices thus provide rich evidence of the textual, discursive construction of human subjectivity in Foucauldian terms, as they combine to create and make knowable a particular category of human (Soyland and Kendall 1997, p.11).

\section{Who are the 'successful girls'?}

The study on which this chapter draws involved interviewing 46 girls aged thirteen to fifteen drawn from the 'gifted and talented' registers in a variety of state comprehensive schools across England; these included mixed and singlesex, suburban and urban schools, with diverse pupil intakes and differing standings in local and national league tables. It also draws on data collected from 'smart girl' participants in a purpose-built web discussion forum involving 134 participants. The diversity of the schools and their pupil populations is important to note. The original 'gifted and talented' register guidelines obliged schools to identify the top $5-10 \%$ of pupils within their own 
cohorts, and this $5-10 \%$ had to be broadly representative of the school population as a whole. This local norm-referencing means that being identified as 'gifted and talented' is highly context-dependent: a girl so identified in one school where average attainment is lower or where girls and boys perform equally, would not necessarily be on the register if she moved to a nearby school with higher attainment or where the proportional quota of girls, or of a minority group to which she may belong, was already filled. Such contextdependency calls attention to the fluidity and instability of 'gifted' identities, even were the validity of the testing and identification regimes that produce them to be established beyond debate. 4 The girls in this study then, are formally identified as 'successful' within particular contextual terms, some of which they demonstrate a keen awareness of, and others they accept uncritically, as I discuss below.

\section{'Gifted and talented' education policy in England: global positioning and governmentality}

Before considering its operation in terms of girls' experiences and subjectivities, it is worth spending some time providing a context for the introduction of 'gifted and talented' education policy in the UK as a particular manifestation of neoliberal success discourse.

\footnotetext{
4 See for example White (2006), who traces the historical roots of Victorian and contemporary intelligence testing in schools to cultures of Puritanism both in the UK and the US, in their notions of pre-destination, their privileging of a particular type of logic, and their doctrines of the salvation of the elect. Also Tomlinson (2003) who argues that what she terms the 'mental testing movement' of the twentieth century with its 'ever increasing refinements to tests of intelligence, ability, aptitudes and competences' provided both justification and self-fulfilling prophecy for the successful middle classes (p.69).Such works expose the processes and contingencies by which the science of ability testing became integral to the design of education systems, policies and practices,
} 
Education is central to the neoliberal self-improvement narrative, in which schooling is a key site where traditional barriers such as class, gender and 'race' are considered dissolved and the only limitations are those of aspiration and commitment. Within this narrative it is a lack of skills and credentials-or a commitment to attaining them - that holds back the individual, rather than economic, social or cultural disadvantage (Patrick 2013, p. 2). 'Gifted and talented' policies were promoted as a means of addressing disadvantage and promoting social mobility through supporting the acquisition of high-level credentials, and became a leitmotif for New Labour's vision of a neoliberal meritocracy.

In his election campaign to become Prime Minister, Tony Blair offered a new model of social justice that was to be achieved through social mobility and individual aspiration. 'Education, education, education' was his mantra, (Blair 1996). His vision drew heavily on the thinking of 'third way' sociologist Anthony Giddens' conception of newly mobile citizens released from traditional fetters of class, imbued with aspiration, capable of reflexivity, and possessing the necessary determination which would combine to secure wellbeing in the place of former state support structures (Giddens 1998). The state, through education, would provide access to the necessary skills and knowledge in the new economy to ensure this. In 1999, the 'gifted and talented' strand of education policy was first implemented via Labour's 'Excellence in Cities' programme targeting urban schools in areas of disadvantage (DERA 2005). At the same time the previous Conservative government's Assisted Places Scheme —intended as a means of sponsoring 
the meritorious poor into private education and thereby promoting social mobility—was abolished.5

'Gifted and talented' policy formed part of a raft of educational programmes that created a specific address to both the anxious middle classes and the aspirant working classes (Tomlinson 2003). This was achieved in part through its continuation of certain aspects of Conservative education policy, namely its commitment to central control of pedagogy and to monitoring through testing while encouraging competition, local markets and 'parentocracy' (Reay 2008, p.640). These strands of intent are neatly encapsulated in a single paragraph in a 2001 government White Paper reflecting on the first four years of the New Labour regime:

Our Excellence in Cities programme...is designed to raise levels of achievement in all urban schools by targeting resources in areas of need and by finding new ways to solve historic problems. A key part was increasing diversity between and within schools, so that schools are better able to reflect parental preferences and develop the talents of each individual pupil to the full (p.15)

'Gifted and talented' policies simultaneously assured middle-class parents that their children would be provided for, and reassured Labour's traditional support base in the initial geographical focus on areas of disadvantage. The success of the appeal to middle-class parents was soon evident in the degree of over-representation of advantaged students on school 'gifted and talented' registers and in the disproportionately low representation of working-class and minority students (Gillborn, 2005; Crozier et al., 2008).

\footnotetext{
5 This scheme had provided funding for eligible children scoring highly in entrance exams to attend independent schools. Costing over $£ 800,000,000$ or approximately $£ 10,000$ per pupil, by the time it folded (Queen's Speech, 1997), it was perceived as both expensive and elitist: most of the 80,000 children benefitting were middle class and white (Edwards et al 1989).
} 
The 'gifted and talented' programme ran formally - that is to say, with specific state policy directives and dedicated funding - from 1999 to 2010. While there is no longer ring-fenced funding, selection by ability continues and indeed has been increased via the fragmentation of the schools system in the name of choice and competition. This includes the resurgence of grammar schools, the creation of 'free schools', and the widespread semi-privatisation of state schools as business-sponsored academies that permit selection by a variety of means (Academies Commission 2013). While the Conservative/LibDem coalition of 2010 dropped the 'gifted and talented' terminology in favour of 'high ability' early in their administration (Smithers and Robinson 2012) and the current government uses the term 'most able', to date many schools still adhere to practices of formal identification, and of distinct curricular provision and extra-curricular enrichment for pupils so identified. 6

Under neoliberal regimes, definitions of educational ability appear to both recognise and discount the role of structural advantage in producing success, paradoxically representing ability as naturalised but its absence resolvable. These definitions are characteristic of the pre-austerity New Labour regime, and the Conservative-led governments that superseded it. Consider for example, Tony Blair's speech at a Labour Party conference in 1996:

We believe that people should be able to rise by their talents, not by their birth or advantages of privilege. We understand that people are not all born into equal circumstances, so one role of state education is to open up opportunities for all, regardless of their background. This means we need to provide high standards of basics for all, but also recognise the different abilities of different children. 
David Cameron's message to the Conservative Party conference in 2013 echoes Blair with his claim that 'opportunity is not an accident of birth, but a birth right' Both endorse a view of inborn 'ability' at the same time as rejecting accident of birth as a determinant of success. It is important to understand these discursive underpinnings of 'gifted and talented' policy, for they play out in schools in ways that offer youth a view on their abilities as naturalised, but at the same indicate that their success is a matter of hard work and taking advantage of educational opportunities. Here it is possible to see a key characteristic of neoliberal subjectivity identified by Foucault - that of natural limitation always being surmountable through the intervention of technology and/or activity (2008, p. 226) - circulate through the domains of political vision, national policy, schools' practice, and the ways in which individual pupils come to understand themselves and others.

\section{The girls in the market and the market in the girls}

In neoliberal discourses of education, conceptions of ability in children are positioned in terms of their economic potential. Pupils are transformed into human capital, their learning as labour. Indeed, the National Academy of Gifted and Talented Youth 7 proposed a national model headed with 'Optimisation of Human Capital' to a House of Commons Select Committee enquiry (2010, p.15). The witnesses at this enquiry justified the investment in such programmes in terms of creating an international intellectual elite that will future-proof the nation's global competitiveness. This discourse carries

\footnotetext{
7Run for the DfES by Warwick University, The National Academy of Gifted and Talented Youth provided extra-curricular activities for secondary school pupils (state and private) deemed to be in top $5 \%$ nationally. It ran from 2002 until 2007. The Guardian's John Crace provides a useful summary of the issues for schools around the Academy and the wider Gifted and Talented initiative, although some of the statistics tend to the apocryphal: https://www.theguardian.com/education/2007/aug/28/highereducation.schools
} 
through from New Labour to the Conservative government, so David Cameron tells the party faithful at conference in 2013 that 'In this world where brains matter more, where technologies shape our lives, where no-one is owed a living...the most powerful natural resource we have is our people'. A 2013 Ofsted report states that:

in an increasingly competitive world...if we are to succeed as an economy and society, we have to make more of our most able young people. We need them to become the political, commercial and professional leaders of tomorrow... we need to make sure that our most able students do as well academically as those of our main economic competitors. (p.4-5)

In schools, 'gifted and talented' initiatives bring discourses of individual achievement and personal goals into alignment with social and economic objectives, through exhorting students to conceive of themselves as ambitious, competitive subjects with responsibility for their own destinies (Bradford \& Hey 2007, p.597), and whose learning is a form of labour investment in their future productivity (Harris 2017).

In the school interviews, it was clear that girls saw themselves as part of this competitive market and adopted its vocabulary. In one school, thirteen year old Amina talked anxiously about the 'job market', worrying, 'that there's gonna be more people out there in the workforce that want the same job,' and describing how 'it makes you feel like, OK, what if I try so hard and do my best but I don't actually get where I want to be? Some girls described how their induction into Year 7 made them worry about not preparing themselves properly for competition later in life: Sonia related her response to her head teacher's talk on her first day at the school: 'That's what got me working. I was just petrified. I walked out of that assembly and I was like 'Oh my God! Oh my God!' Since then, I've worked.' 
The girls also recognised that, in the same way that they themselves are encouraged to develop a conception of the 'successful' self as competitive and individualist, so too are others, and this makes them uneasy. Tanya described her anxieties over her relationships with future colleagues who will see her as the competition, and over the workplace characterised by hierarchical rather than collegiate relationships:

If you're smart then you're probably more likely to get a better job and things...more likely to, um, be more successful when you're older. But then, that's...it's good stuff but then, I dunno it's just like... the people in your workplace will be like the same as you, kinda like, will want the same things as you. But then there's other people who are like, might be above you. Who will be like, kind of looking down on you and then...so it's like... I dunno

Alison agreed with her: she was ambivalent at best about the 'successfulwoman-as-role model' discourse that is characteristic of neoliberal feminisms such Sheryl Sandberg's Lean In (2013) and its girl-orientated younger sister, the 'Ban Bossy' programme (2014). Her comment is particularly interesting in its recognition that successful women are penalised for their success. This runs directly counter to postfeminist narratives of gender equality in the workplace as achieved, and to 'successful girl' discourses that tell her she can grow up to be/do anything she wants.

Her reply to Tanya was as follows:

I dunno. I think that, um, smart women are looked up to in the workplace, like, people ... try to use them like to try and do better as well. But then like they're kind of like despised as well because...you don't want them... because they have the same ambitions in the same job. You don't want them to get the better job because that's a disadvantage against you 
because it's kind of like dog-eat-dog, so if you don't get it you kind of miss out so you despise them sometime

Alison's anxieties illustrate ways in which a dominant neoliberal success discourse - that of competition - may not be incompatible with other kinds of wellbeing. Her fear of being despised is matched by a fear that she may become somebody who despises others. Here we see at work the 'socially corrosive ethic of competitive self-interest' underpinning neoliberal meritocracy as described by Jo Littler (2013, p.54). There are no other possible roles than winner and loser on offer. This same argument is being played out in feminist philosophy, in exploration of the claims to a new 'compatibilism' in neoliberal feminisms. These claims assume that tensions between feminism and competition are resolved and that, rather than implicating women in the perpetuation of domination, greater representation in privileged positions is a means to achieving change (Cawston 2016 p.206). The examples above illustrate how the language and self-conceptions of the neoliberal market have 'got inside' the girls, but suggest that the colonisation of the girls' sense of selfhood and their visions of successful lives is not complete. This incompleteness is interesting in its suggestion that while the girl may be the 'ideal neoliberal subject' insofar as neoliberal discourse aligns with that of postfeminism, there are irreconcilable tensions with the competitive heart of neoliberal subjectivity,

\section{Meritocracy and the daughters of neoliberalism}

'Gifted and talented' policies have at their core a belief in meritocracy—or, a system in which individuals are apparently rewarded according to what they can do rather than who they are. This concept is as problematic as it is chimerical (Tomlinson, 2008; Littler 2017). Its core assumptions are highly 
debatable in themselves (i.e. the existence of essential, measurable merit), unfair in those assumptions (i.e. that those fortunate enough to be born with innate talent should alone have the means to access a good life) and are dependent on systems that can deliver distributive justice and equality of opportunity to achieve social mobility (Liu 2011): those very structures that neoliberal government seeks to dismantle.

Littler (2017) provides an incisive summary of how the popularisation of meritocracy provides both a cornerstone and a smokescreen for neoliberalism's promotion of gross inequalities:

Meritocracy, as a potent blend of an essentialised notion of 'talent', competitive individualism and belief in social mobility, is mobilised to both disguise and gain consent for the economic inequalities wrought through neoliberalism.

The extent to which this supposedly meritocratic system can work to benefit the already advantaged while concealing its own inherent injustices can be seen in 'gifted and talented' policy discourses that normalise its appeal to middle-class parents, while at the same time shifting the burden of blame for some pupils' failure onto working-class parents, and, as they grow, onto children themselves. New Labour's mobilisation of discourses of individuation, blame, and aspiration can be seen in the language in which it sets out its aims in its first education white paper, Excellence in Schools:

To overcome economic and social disadvantage and to make equality of opportunity a reality we must strive to eliminate, and never excuse, under-achievement in the most deprived parts of our country. Educational attainment encourages aspiration and self-belief in the next generation, and it is through family learning, as well as scholarship through formal education, that success will come (DfEE 1997) 
The same discourse appears more starkly and the 'othering' more extreme in David Cameron's speech to the Conservative party in 2013:

It's OK for the children who have parents reading them stories every night - and that's great ... but what about the ones at the back of the class, in the chaotic home, in the home of the drug addict or alcoholic?

A focus on aspiration frames disadvantage as at root a cultural problem rather than an economic problem. Within neoliberal education narratives, the role of parents as partners and co-educators through provision of learning environments, resources and appropriate attitudes is now central (Reay 2008). This has implications for the perceived locus of failure which shifts from structural inequalities to fall on the shoulders of working-class parents (Lucey, Melody and Walkerdine 2003, p.289).

The government's investment in the idea of the individual as reflexive and resilient neoliberal subject is also manifest: unpicking some of the narratives reveals patterns of the 'right' kind of parents working with the education system to provide opportunity for the individual pupil as the ultimate producer of her own destiny.

The reproduction of discourses of parenting, of class, and of self-responsibility emerged in girls' accounts both of their own successes and of the failures of others. Parents were described as providing both structures and opportunities. These include formal learning at home and the provision of cultural experiences such as museum and theatre visits. Restrictions on media use also appear important, both old media (television) and new (phones and laptops), as well as support with school work. Shameem said that success starts with 'how your family brings you up to learn, and how they help you when you're 
learning, like in school.' Sally offered this account of her family's role in producing her high attainment:

I was taught to read and write before I went to school, so it all kept me motivated...There was a certain routine when I got home... like I've never been used to going home, sitting in front of the TV in my school uniform and not doing my homework. It was always, 'Come on then! Take off your uniform and do your homework

Sally's description also conjures the spectre of the 'other' kind of laissez-faire parenting, in which TV is unrestricted, homework unmonitored and moral slovenliness indicated through failure to change clothing.

Girls whose parents do not take up the mantle of family educator in this way described themselves as assuming the responsibility themselves for their success. However, ways in which they experienced that responsibility varied according to their class position and to the kinds of educational discourse to which they had access. When working-class interviewee Sonia declared, ' $M y$ parents don't really care if I do homework or not, but I still do it' she did so with a blend of pride in her self-management and shame in her parents' lack of concern. In contrast, two of the middle-class interviewees rather proudly invoked an anti-authoritarian parenting model which sits more comfortably with liberal rather than neoliberal education discourse: Dora described how 'There's all these parents' that work their kids really intensively and my parents don't really care if I get an F or an A, and that's helped because I don't feel pressured'. Lydia concurred, saying, 'the more pressure, the more somebody hammers on to you about doing something, the more you just don't wanna do it'. While both Dora and Lydia presented themselves as selfmanaging subjects, they could do so in a way that attached no blame to their parents; in fact, Lydia presented this kind of parenting as ethically superior. 
Their ability to frame their parents' attitudes within a recognisable alternative to the dominant neoliberal education discourse frees them from the shame of parental inadequacy that is attached to Lydia's experience.

\title{
Working hard and deserving success
}

The idea that girls' achievement is produced by application rather than inspiration has long held sway in the wider imaginary 8 and this association of diligence with girls' success is a key seam of alignment with the successful, self-managing subject of neoliberalism. This means that school discourses of meritocracy can weigh more heavily on successful girls than on their male counterparts, as the kinds of subject positions associated with effortless, erratic success, or with non-compliant behaviours, are not as easily available to them. In their navigations around the 'hard-working girl' trope some of the girls offered a challenge to the idea that their success is produced by diligence alone. For example, success came quite easily to Sally, yet she was aware that her status on the 'gifted and talented' register was understood as tied to effort:

\begin{abstract}
It's really weird actually because I'm supposed to be 'gifted and talented' but if I like, sit back and think over the last couple of months I don't even know if I push myself that hard and apparently, I did well and I feel like... I didn't feel like I put like, my whole self into it because I don't really know what it's like to work really really hard...
\end{abstract}

Others described the hard-working girl identity as one which enables them to balance the competing demands of academic success and femininity, through avoiding the effortless success model associated with masculinity (Renold and Allan 2006). The appearance of 'working hard' can also act as a kind of 
performance smokescreen-for example Jurda described how she was able to get work done quickly in class, then avoid further teacher demands while furtively occupying herself with something she enjoyed more: 'most people think I study a lot, but instead I love to read fiction.'

Girls demonstrated awareness that diligence and compliance are central to their identification as successful in the classroom. Sally made this clear in her descriptions of how, for other girls,

it's like, almost all right for them to not work...It's that they can have a bit of, um, a muck-about and if you muck about even a little bit......it's like, oh my god! She mucked about! It's supposedly like you're genetically programmed to never do anything wrong

For those whose academic success is performed in less complaint ways, that nonetheless do 'muck about', the risks of non-conformity are illustrated in the experiences of Kelly, a working-class interviewee. She described how:

I'm not an angel and that. I get sent out a bit and I talk a lot and stuff like that so people don't think I'm clever, but I am. In my maths lesson I get sent out nearly every lesson but I don't know why 'cause I'm still quite good at it

Dora concurred, reporting that 'A few people got moved down (from the 'gifted and talented set) because they had bad behaviour, but they were really smart. And it just seemed a bit unfair'.

These strategies for managing 'successful girl' identities-teacher-pleasing, adopting compensatory feminine behaviours, appearing to work hard, flouting behavioural expectations - are not equally available to all girls. The hardworking 'good' girl is particularly associated with white, middle-class identities (Archer 2005), but carries more negative associations for some minority groups who may be perceived as overly passive (Archer and Francis 
2006). Non-compliance is associated with working-class pupils' resistance to the cultures of schooling in which historically they have failed (Hey 1997; Archer, Halsall, and Hollingsworth, 2012). Such strategies are not equal in the risks they represent. While the hard-working compliant girl may risk social censure from her peers in the short term-for example, Anna described not wanting to 'act smart in case a certain group of girls don't like this'-the risks for the girl who is continually sent out of class or barred from top sets are more significant and potentially far-reaching.

Some interviewees gave accounts of success and failure that reproduced morality discourses attached to hard work and self-improvement, reinforcing neoliberal tenets of success as a matter of aspiration and application. Isobel maintained that 'No matter what you are you can get what you want'; Tanya, that you will succeed 'if you kind of believe in yourself and believe you can do it'. When I asked the girls if they thought it possible for anyone in the school to be as successful as them, they agreed. Adele said that some of her peers 'could be really smart if they pushed themselves'. Nicki offered the following mini-narrative:

You came to a point and you wanted to try harder. To be like, where the high people were. Like for example if you was in a lower set in Year 7 and you look up to the people and you try and work harder to get to that point 
But when I asked her if this story was about her she laughed and replied, 'No! I was already in top sets.' This suggests how ideas of meritocracy work in schools to provide pupils with accounts of success and failure that allow them to see themselves as deserving and others as less so, even when these accounts do not accord with the evidence of their own experience.

The girls struggled to express awareness of the operations of class in their schools, and tended to frame it both euphemistically and in ways that reproduce neoliberal stigmatisation. Holly described how peer identification means that 'there are some people who don't work as hard as each other...they don't work as hard, like with that group of people'; Poppy accounted for under-achievement as a matter of individual valuing of 'cool' over 'school', saying, 'there are some girls I guess that don't...that probably want to seem more cool than care about their, like, education'. Sally recognises a link between class identity and school success and expresses it as 'certain people who are really clever but they're of a certain social group where they're supposed to be the 'muck about' people.'

The 'hard-working girl' narrative provides few explanations for failure and occludes the role of advantage in producing success. For some of the girls in the study, there are others among the participants whose 'successful' identities are less secure, this is problematic. Where they have invested in the hardworking success model they have no explanations for their classmates' failure other than individual inadequacy. Bradford and Hey (2007) describe 'success' discourses in neoliberal education systems in the UK as representing, 
a new twist on redistribution in the sense that the discursive tactics entailed seek to inscribe young people from disadvantaged backgrounds with confidence and resilience in the face of psychological and social pressures (p.601)

This entails the development of what they term 'psychological capital', of which a key characteristic is the desire to improve the self. Failure therefore implies a failure in appropriate desires or in carrying through such desires into reality, rather than in the structures necessary to foster success. In some of the girls interviewed there is evidence of the failure of this 'psychological capital' model to inscribe resilience. Farida describes her ambition to become a lawyer and recognises that it is 'really hard work'. She contemplates not achieving this goal by saying 'I don't think I have the ability to do it'. Living in one of London's poorest boroughs, Farida learned English as a second language and performed well enough to gain a place on the school's 'gifted and talented' register. However, the neoliberal self-improvement narrative stresses success as the outcome of individual effort and aspiration. It does not offer her an account in which she might understand her not having attained the grades she wants and therefore plan her life narrative, outside of a failure of her own 'ability'. Amina asked the group: 'OK, what if I try so hard and do my best but I don't actually get where I want to be? And then it's just...yeah [holds hands up in gesture of defeat]. The other girls had no answer for her.

\section{Choosing not to invest}

The previous examples explore negotiations with taking up the 'successful girl' subject position; an example I found particularly compelling emerged from the conversation with two girls who refused to create life-plans according to the neoliberal self-improvement model. They are 'successful girls' insofar as they achieve good grades; they have further 'earned' their 
places on the 'gifted and talented' register through their diligence and compliant behaviour. However, while they seemed secure in their academic achievements and profess to enjoy school, they refused to conceive of their work as investment of labour in their futures, and to develop the kinds of 'psychological capital' described by Bradford and Hey above. They are of interest because both are working class and are typical of the cohort among which the school wishes to foster aspiration. Further, both had been identified as potential beneficiaries of careers service intervention, which marks them as causing particular concern. Under New Labour, careers advice in schools was delivered via the Connexions service, which was tasked to ensure transitions into work or further/higher education particularly among the disadvantaged, the at-risk and the undecided (Morris et al. 2001). It was more unusual for pupils identified as 'gifted and talented' to be referred, although when the service was established anxieties were expressed that,

failing to recognise that 'academically able young people also need access to guidance and support to make successful transitions' would lead, in future, to increased levels of dropout from both further and higher education (p.30)

Kara described her response to being targeted by the service:

I saw the Connexions person, the guidance counsellor. And he um, he was trying to, like, give me options that were like better for my grades. That were more...that would be like better jobs than what I actually wanted, just 'cause I could get them...cause I'm a high achiever But, like, I don't really wanna do that [smiles apologetically]

Her friend Nicki offered a similar story: 'Yeah. I went to the Connexions guy... and he gave me all these options. And it kind of put me off.' 
While Connexions was abolished by the Conservative-led coalition government in 2011 and replaced by in-school provision, the principle of the less-advantaged pupils being the chief beneficiaries was continued. University-bound pupils were assumed to have parents who could advise them, and to be able to access wider networks of information and support. This was borne out in the study, with more privileged girls drawing on family narratives of university life, proclaiming the benefits of gap years, telling stories of family members' experiences, and offering parental perspectives on university and course choices. Some rated their parents' expertise over that of their teachers, and a dominant narrative among this group was the expectation that they would not only participate in but would enjoy university. A further group of girls was more dependent on the school for advice, less knowing about what university life might entail and more anxious about its risks and benefits. Some asked how many years a degree might take, and whether students were allowed to live at home. Accumulating debt and uncertainty about financial benefits in terms of future earnings were a source of anxiety, as was the amount of work a degree might entail. Nonetheless, these girls too saw university as an essential stage in a prescribed successful life-course, and one for which the risks of omission far outweighed those of pursuit. Shameem described the steps as a kind of a mantra: 'It's like, primary school, high school, college, university' and Sally feared that if she didn't go, and go straight from school, 'I'll never get anywhere. So I really wanna get things right, like, in order'. Sonia (who had earlier described the fear instilled by her head teacher in Year 7) was aware of the stigmatising judgement attaching to those who do not properly aspire, and sees the government as the source of this: 
I think I'm pretty sure I want to go to university and like pass A levels and stuff...because I think, these days, like government requirements to get a job, they judge you more on like if you've been to university. If you haven't really been to university it's like...I dunno

Set against these narratives of entitlement and anxiety, Kara and Nikki's refusal of social mobility can be understood as a refusal of the losses it entails rather than the gains it promises. As Littler (2013, p.55) observes, the language of meritocracy is about moving 'upwards' in financial and class terms' but does not necessarily entail 'existing in a 'better' or 'happier' culture'. And while the upward movement is invariably away from workingclass cultures that under neoliberalism have become locations of cultural shame and personal stigma (Tyler 2013; Walker 2014), for working-class girls this movement may represent loss in terms of family and community, as well as psychological harm in terms of the shame that adheres to working-class identities (Lucey, Melody and Walkerdine, 2003; Hey 2003). Such a restriction of success to individual wealth and status constitutes is at the core of the problematic neoliberal vision of ways education can contribute to the 'good' life.

\section{Conclusion}

In offering a particular vision of success, 'gifted and talented' policies can be seen to reaffirm discourses of gendered difference, of human capital, and of classed 'ability' while preserving and promulgating the comforting meritocratic myth. The creation of the specific identity of 'gifted and talented' in schools, its underpinning assumptions; its language; the technologies of registers and reporting, and the practices of grouping and career-counselling, all work to shape the social and material conditions for pupils so identified, 
and create new subject positions by which they are interpellated as gifted (or not), meritorious (or underserving), and successful (or failing).

In concluding this chapter, I return to Gill and Scharff (2011)'s call for more considerations of the 'mentality' aspects of neoliberal governmentality. I have offered examples that make it possible to see the 'government' get inside the subject in a range of ways - in the direct transfer of the language of economic policy to the pupil through exhortations in school assemblies; in the more subtle incursions of discourses of supportive parenting; and in the divide-andconquer workings of differentiated discourses of aspiration to higher education. These examples, however, only give a partial account; others, from girls who do not fully buy into the 'successful girl' subject position, offer the possibility of alternatives. Not all of these alternatives are necessarily or knowingly resistant; it is great deal to expect that they should be so, and we should to attend to Harris and Dobson's (2015, p.146) caution against placing the loaded expectation of resistance onto the next generation of girls in the hope that they will be more impervious, more knowing, more capable of instigating change than were we. And as Gonick et al. (2009, p.6) observe, girls' agency is 'practiced within normative social, economic and political processes' that shape their lives and selfhoods. Some of the girls find alternatives within complicity - they do the school work and the identity work - but they also recognise the constraints and manipulate or evade them, for example those girls who use the hard-working identity as camouflage to give themselves time/space for other pursuits. Others adopt class and culturally specific forms of resistance, for example the girls who refuse to adopt the gendered and classed behaviours expected of them; the girls who take pride in their parents' dissent; and the girls who are unwilling to forfeit community and connectedness for individualism and status. 
It is tempting to romanticise some of this refusal, not least if one is coming from the position of a middle-aged academic who, as working-class girl, did not refuse the lures of aspiration. It is also important to keep in mind the psychological costs of aspiration, in terms of insecurity of identity and the shame that attaches to working-class origins in many middle-class educational and professional cultures. Our challenge is to offer alternative narratives in which learning is not valued solely as an economic investment, and to create cultures in our schools and universities where success is less bound up in class, gender, less shaped by individualism and competition9. As Naomi Klein (2017) reminds us, 'There were always other stories, ones that insisted that money is not what's valuable, and that all of our fates are intertwined with one another'; it is these stories that should be brought to the fore - and the strategies to make them realisable - as we create the conditions for life beyond neoliberalism. 


\section{References}

Academies Commission (2013) Unleashing Greatness: Getting the best from an academised system RSA http://www.academiescommission.org/?s=

Allen, K. (2016) Top girls navigating austere times: interrogating youth transitions since the 'crisis'. Journal of Youth Studies, 19:6, pp. 805-820

Archer, L. and B. Francis (2006) 'Challenging Classes? Exploring the Role of Social Class within the Identities and Achievement of British Chinese Pupils', Sociology 40:1, pp.29-49.

Austin, J.L (1976) How to Do Things with Words, Cambridge: Harvard University Press.

Ban Bossy (2014) http://banbossy.com/

Bernstein, B. (1977) Class, Codes and Control: Vol. 3. London: Routledge

Blair, Tony (1996) Speech to Labour Party Conference. October 1996. http://www.britishpoliticalspeech.org/speech-archive.htm?speech=202

Butler, J. (1997) Excitable Speech: A Politics of the Performative, New York \& London

Cameron, David (2013) Speech to the Conservative Party Conference. October 2013. https://www.telegraph.co.uk/news/politics/david-cameron/10349831/David-

Camerons-speech-in-full.html

Cawston, A, (2016) Are Feminism and Competition Compatible? Hypatia: A journal of feminist philosophy 31:1, pp.204-220

Crittenden, Brian (2006) The School Curriculum and Liberal Education. Education Research and Perspectives, 33:1, pp.105-127

Crozier, G., Reay, D., James, D., Jamieson, F., Beedall, P., Hollingworth, S. and Williams, K. (2008) White middle-class parents, identities, educational choice and the urban comprehensive school: dilemmas, ambivalence and moral ambiguity. British Journal of Sociology of Education, 29:3, pp.261-272.

De Henau, J. and Reed, H. (2013) A cumulative gender impact assessment of ten years of austerity policies. Women's Budget Group. https://wbg.org.uk/wpcontent/uploads/2016/03/De HenauReed_WBG_GIAtaxben_briefing_2016 03 06.pd $\underline{f}$

DERA: OfSTED (2005) Excellence in Cities Available at:

http://dera.ioe.ac.uk/5642/1/Excellence $\% 20 \mathrm{in} \% 20$ Cities $\% 20$ managing\%20associated \%20initiatives $\% 20$ to $\% 20$ raise $\% 20$ standards $\% 20 \% 28 \mathrm{PDF} \% 20$ format $\% 29$.pdf

DfEE (1997) Excellence in Schools, DfEE publications. 
DfES (2001) White Paper: Schools Achieving Success. DfES publications

DfES (2006) Identifying gifted and talented pupils: Getting started. DfES publications

Edwards, A. D. Fitz, J. and Whitty, G (1989) The State and Private Education: An Evaluation of the Assisted Places Scheme. London: Falmer

Foucault, M. (1993) About the beginning of the hermeneutics of the self (transcription of two lectures in Dartmouth on 17 and 24 November 1980). Ed. M. Blasius, Political Theory, 21:2, pp.198-227.

Foucault, Michel (2008) "The Birth of Biopolitics" Lectures at at the Collège de France 1978-1979. Trans. Graham Burhcell. New York: Palgrave Macmillan

Foucault, M (2009) Security, Territory, Population: Lectures at the College De France, 1977-78. Ed. Arnold I. Davidson. Basingstoke: Palgrave Macmillan

Francis B. and Hey, V. (2009) Talking back to power: snowballs in hell and the imperative of insisting on structural explanations. Gender \& Education, 21:2, pp.225232

Giddens, A. (1998) The Third Way: The Renewal of Social Democracy. Cambridge: Polity Press

Gill, R. and Scharff, C. (2011) New Femininities: Postfeminism, Neoliberalism and Subjectivity Basingstoke: Palgrave Macmillan

Goldthorpe, John H. (1987). Social Class and Mobility in Modern Britain, 2d ed. Oxford: Clarendon Press.

Gonick, M. (2006) Between girl power and reviving Ophelia: Constituting the neoliberal girl subject. National Women's Studies Association Journal, 18:2, pp.1-23.

Harris, A. (2004) Future Girl: Young Women in the Twenty-first Century. Abingdon: Routledge

Harris, M. (2017) Kids These Days: Human Capital and the Making of Millennials New York: Little, Brown \& Company.

Hey, V. (2003) Joining the Club? Academia and Working-class Femininities. Gender and Education, 15:3, pp.319-335

Hollows, J. and Moseley, R. (2006) Popularity contests: the meaning of popular feminism. In J. Hollows and R. Moseley (Eds.) Feminism in Popular Culture. Oxford: Berg.

House of Commons Select Committee: Children, Schools and Families Committee (2010). The Gifted and Talented Programme. London: The Stationery Office Limited Jackson, C. (2006) Lads and Ladettes in School: Gender and a Fear of Failure. Maidenhead: Open University Press 
Jackson, C. and Nyström, A.S. (2014.) 'Smart students get perfect scores in tests without studying much': why is an effortless achiever identity attractive, and for whom is it possible? Research Papers in Education 30:4, pp.393-410

Littler, J. (2013) Meritocracy as Plutocracy: The Marketising of 'Equality' Under Neoliberalism. new formations: a journal of culture/theory/politics, 80: 80, pp.52 -72

Littler, J. (2017) Against Meritocracy: Culture, Power, and Myths of Mobility London: Routledge

Liu, W.M. (2011) Developing a social class and classism consciousness The Oxford Handbook of Counseling Psychology (Eds)by Elizabeth M. Altmaier and Jo-Ida C. Hansen. Oxford: OUP

Lucey, H., Melody, J. and Walkerdine, V. (2003) Uneasy Hybrids: psychosocial aspects of becoming educationally successful for working-class young women. Gender and Education, 15:3, pp.288-299

Klein, N. (2017) Daring to Dream in the Age of Trump https://www.thenation.com/article/daring-to-dream-in-the-age-of-trump/

McRobbie, A. (2008). The aftermath of feminism: Gender, culture and social change. London: Sage.

Mendick, H. (2013) Modern Girlhoods. Sociological Research Online 18:2 23 https://doi.org/10.5153/sro.3113

Mendick., H., Allen, K., Harvey, L. and Ahmad, A. (2018) Celebrity, Aspiration and Contemporary Youth: Education and inequality in an era of austerity. London:

Bloomsbury

Morris, M, Rickinson, M. and Davies, D (2001) The Delivery of Careers Education and Guidance in Schools. DES/National Foundation for Educational Research. Research Report no.296. HMSO

Office for Natuonal Stataistics (ONS) Women in the labour market https://www.ons.gov.uk/employmentandlabourmarket/peopleinwork/employmentande mployeetypes/articles/womeninthelabourmarket/2013-09-25

OfSTED (2013) The most able students: Are they doing as well as they should in our non-selective secondary schools?

https://assets.publishing.service.gov.uk/government/uploads/system/uploads/attachme nt data/file/405518/The most able students.pdf

Paule, M. (2015) Dinosaur Discourses: Taking stock of gendered learning myths. Gender and Education 27: 7, pp.744-758

Paule, M. (2016) Girlhood, Schools and Media: Discourses of the achieving girl in schools, on screen and online Abingdon/New York: Routledge 
Patrick, F. (2013) Neoliberalism, the Knowledge Economy, and the Learner:

Challenging the Inevitability of the Commodified Self as an Outcome of Education. ISRN Education, Vol. 2013, Article ID 108705, 8 pages, doi:10.1155/2013/108705

Power, S. (2000) Educational pathways into the middle classes. British Journal of Sociology of Education, 21:2, pp.133-145

Queen's Speech (1997) BBC Politics Archive. http://www.bbc.co.uk/news/special/politics97/issues/education.shtml

Reay, D. (2008) Tony Blair, the promotion of the 'active' educational citizen, and middle-class hegemony. Oxford Review of Education, 34:6 pp.639-650

Renold, E. and Allan, A. (2006) Bright and Beautiful: High achieving girls, ambivalent femininities, and the feminization of success in the primary school. Discourse: Studies in the Cultural Politics of Education, 27:4, pp.457-473

Ringrose, J. (2007) Successful girls?: Complicating post-feminist, neo-liberal discourses of educational achievement and gender equality. Gender and Education, 19:4, pp.471-489

Ringrose, J. (2013) Postfeminist Education? London: Routledge

Ringrose, J. and Epstein, D. (2017) Postfeminist Educational Media Panics, Girl Power and the Problem/Promise of 'Successful Girls' In (eds) M. Pteres, B. Cowie and I.Menter, A Companion to Research in Teacher Education. Singapore, Gateway East: Springer

Rizvi, F. and Lingard, B. (2010) Globalizating Education Policy. New York: Routledge.

Sandberg, S (2013) Lean In: Women, Work and the Will to Lead New York: Knopf

Skelton, C. Francis, B. and Read, B. (2010) Brains before 'beauty'? High achieving girls, school and gender identities. Educational Studies, 36:2, pp.185-194

Smithers, A, and Robinson, P. (2012) Educating the Highly Able. Research report for the Sutton Trust. http://www.suttontrust.com/research/educating-the-highly-able/

Soyland, A. and Kendall, G. (1997) Abusing Foucault: Methodology, critique and subversion. History and Philosophy of Psychology, pp. 9-17.

Tomlinson, S. (2008) Gifted, talented and high ability: selection for education in a one-dimensional world. Oxford Review of Education, 34:1, pp.59-74,

Tyler,I (2013) Revolting Subjects: Social abjection and resistance in neoliberal Britain, London, Zed Books

Walker, R. (2014) The Shame of Poverty Oxford: OUP

Wilkinson, H. and Howard, M (1997) Tomorrow's Women. London: DEMOS 